\title{
Purification and Properties of Chromosomally Mediated $\beta$-Lactamase from Citrobacter freundii GN7391
}

\author{
By M. TAJIMA, ${ }^{1 *}+$ Y. TAKENOUCHI, ${ }^{2}$ S. SUGAWARA, ${ }^{2}$ \\ M. INOUE ${ }^{1}$ AND S. MITSUHASHI ${ }^{1}$ \\ ${ }^{1}$ Department of Microbiology, School of Medicine, Gunma University, \\ Maebashi, Gunma 371, Japan \\ ${ }^{2}$ Central Research Laboratories, Sankyo Co. Ltd, Tokyo 140, Japan
}

(Received 26 February 1980; revised 19 May 1980)

\begin{abstract}
Both a penicillinase and a cephalosporinase are present in a strain of Citrobacter freundii (GN7391) resistant to $\beta$-lactam antibiotics. The penicillinase was identical to the type Ia penicillinases (Type III by Richmond classification), mediated by Rms 212 and R-TEM. A cephalosporinase, typical of enterobacteriaceae chromosomal $\beta$-lactamase (Type I by Richmond classification), was purified from the strain. It gave a single protein band on polyacrylamide gel electrophoresis and immunoelectrophoresis; the pI was 8.6 and its molecular weight was approximately 38000 . Cysteine was not found among its amino acids. The specific activity was 388 units (mg protein $)^{-1}$ for the hydrolysis of cephaloridine, and the optimal $\mathrm{pH}$ was 8.0. Rabbit antiserum obtained against the purified enzyme showed cross-reaction with cephalosporinases produced by strains of Enterobacter cloacae in a neutralization test.
\end{abstract}

\section{INTRODUCTION}

$\beta$-Lactam antibiotics show relatively poor activity against Citrobacter freundii (Verbist, 1976; Bill \& Washington, 1977). Many strains of $C$. freundii produce an inducible cephalosporinase, considered to be the 'species-specific' $\beta$-lactamase (Sawai et al., 1968). Some properties of the cephalosporinase have been investigated and compared with $\beta$-lactamases of other bacteria, using crude enzyme preparations (Sawai et al., 1970b; Newsom et al., 1974).

In the present work, we have studied some of the physical, chemical and immunological properties of a $\beta$-lactamase produced by a strain of Citrobacter freundii. The neutralization reaction with a rabbit antiserum prepared against the purified $\beta$-lactamase is also reported.

\section{METHODS}

Antibiotics. The $\beta$-lactam antibiotics used (see Results) were gifts from their respective manufacturers. Bacterial strains and identification. All the strains of Citrobacter freundii studied were isolated from clinical sources and were maintained in cooked meat medium (Eiken Chemical Co., Tokyo, Japan). Species were identified according to the scheme of Cowan \& Steel (1974).

Antibiotic resistance. Minimum inhibitory concentrations of various $\beta$-lactam antibiotics were determined by using twofold dilutions in heart infusion agar (Eiken Chemical Co.) with an inoculum of $10^{4}$ organisms.

Culture and harvesting of organisms. Trypto-soy broth (2 1; Eiken Chemical Co.) in a 51 flask was inoculated with $100 \mathrm{ml}$ of an overnight culture at $37^{\circ} \mathrm{C}$ and incubated on a rotary shaker at $37^{\circ} \mathrm{C}$. After $4 \mathrm{~h}$, the

$\dagger$ Present address: Central Research Laboratories, Sankyo Co. Ltd, 1-2-58 Hiromachi, Shinagawa-ku, Tokyo 140, Japan. 
bacteria were harvested by centrifuging and washed once with $0.15 \mathrm{M}-\mathrm{NaH}_{2} \mathrm{PO}_{4} / \mathrm{Na}_{2} \mathrm{HPO}_{4}$ buffer, $\mathrm{pH} 7.5$. The packed cells were resuspended in $200 \mathrm{ml} 1 \mathrm{~mm}$-phosphate buffer, $\mathrm{pH} 7.5$ and the suspensions were treated for $4 \mathrm{~min}$ in an ultrasonic disintegrator $(80 \mathrm{~W}, 25 \mathrm{kHz})$. The disrupted suspensions were centrifuged at $10000 \mathrm{~g}$ for $20 \mathrm{~min}$ at $5^{\circ} \mathrm{C}$ to remove unbroken cells and cell debris; the cell-free extract was retained as the crude enzyme preparation. Protein was determined by the Lowry method.

Purification of $\beta$-lactamase. (All buffer solutions were $\mathrm{NaH}_{2} \mathrm{PO}_{4} / \mathrm{Na}_{2} \mathrm{HPO}_{4}$ unless otherwise stated.)

To the cell-free extract, streptomycin sulphate was added to give $1.5 \%(\mathrm{w} / \mathrm{v})$. After removing the precipitate by centrifuging $(10000 \mathrm{~g}$ for $20 \mathrm{~min})$, the supernatant was dialysed overnight against distilled water and then against $215 \mathrm{~mm}$ buffer, $\mathrm{pH} 7 \cdot 2$. The precipitate formed during dialysis was removed by centrifuging and the supernatant (step 2) was passed through a Sephadex CM-50 column $(2.3 \times 30 \mathrm{~cm})$ equilibrated with $5 \mathrm{~mm}$ buffer, $\mathrm{pH} 7 \cdot 2$. The first peak contained a large amount of inactive protein and an R plasmid-mediated penicillinase. This penicillinase was purified by the methods of Yamanaka et al. (1973), with chromatography through DEAE-cellulose.

The chromosomal cephalosporinase appeared in the second peak after elution with $0.05 \mathrm{M}$ buffer, $\mathrm{pH} 7.2$ (step 3). This second peak was applied to another Sephadex CM-50 column $(2.3 \times 17 \mathrm{~cm})$ and after washing with $300 \mathrm{ml} 0.01 \mathrm{M}$ buffer, $\mathrm{pH} 7.2$, was eluted with $300 \mathrm{ml}$ linear gradient of 0.01 to $0.05 \mathrm{M}$ buffer, $\mathrm{pH} 7.2$. The active fractions (eluted with 0.024 to $0.026 \mathrm{M}$ buffer) were pooled and then dialysed against distilled water (step 4).

The dialysed solution (about $20 \mathrm{ml}$ ) was used for isoelectric focusing (see below; step 5). Fractions around the peak of enzyme activity (fractions 43 to 47 , see Fig. 1) were pooled and applied to a Sephadex G-200 column $(2.3 \times 86 \mathrm{~cm})$ equilibrated with $0.05 \mathrm{M}$-Tris $/ \mathrm{HCl} / 0.1 \mathrm{M}-\mathrm{NaCl}$ buffer, $\mathrm{pH} 8.0$ and eluted with the same buffer (step 6). Active fractions were dialysed against distilled water and then lyophilized.

Isoelectric focusing. Isoelectric focusing was performed on a sucrose/ampholytes gradient (pH 3.5 to 10). Enzyme solution from step $4(10 \mathrm{ml})$ mixed with $0.75 \mathrm{ml}$ Ampholine in $60 \mathrm{ml}$ total volume was used as the 'light solution'. The 'dense solution' contained the remaining enzyme solution, $2.25 \mathrm{ml}$ Ampholine and $28 \mathrm{~g}$ sucrose in $60 \mathrm{ml}$ total volume. The cathode (bottom) was filled with a solution consisting of $12 \mathrm{~g}$ sucrose, $0.2 \mathrm{ml} \mathrm{H}_{3} \mathrm{PO}_{4}$ and $14 \mathrm{ml}$ distilled water. To prevent contact between the ampholytes and the anode (top), a solution containing $0.1 \mathrm{~g} \mathrm{NaOH}$ in $10 \mathrm{ml}$ distilled water was added at the top of the column. Experiments were carried out at $5^{\circ} \mathrm{C}$ in the LKB 8100 column over $72 \mathrm{~h}$ at $300 \mathrm{~V}$. The column contents were then fractionated into $2 \mathrm{~g}$ per tube.

Polyacrylamide gel electrophoresis. The purity of the enzyme preparations was checked by discontinuous gel electrophoresis as described by Davis (1964), using $7.5 \%$ (w/v) polyacrylamide gel, $\mathrm{pH} 4 \cdot 3$, as the separation gel. Electrophoresis was carried out in duplicate gels: one was stained with Coomassie Brilliant Blue R250 and the other was cut into slices $4 \mathrm{~mm}$ thick. The slices were disrupted in $1 \mathrm{ml} 0.01 \mathrm{M}$ buffer, $\mathrm{pH} 7.5$ and the $\beta$-lactamase activity was measured.

Determination of molecular weight. The molecular weight of the enzyme was determined by gel filtration through Sephadex G-200 with 0.05 $\mathrm{M}$-Tris/HCl/0.1 $\mathrm{M}-\mathrm{NaCl}$ buffer, $\mathrm{pH} 8.0$, as described by Andrews (1964), and by sodium dodecyl sulphate (SDS)-polyacrylamide slab gel electrophoresis according to Weber \& Osborn (1969), using bovine serum albumin (mol. wt 67000), ovalbumin (45000), chymotrypsinogen (25700) and lysozyme (14400) as molecular weight standards.

Assay of $\beta$-lactamase. Hydrolysis of $\beta$-lactam antibiotics was assayed spectrophotometrically ( $\mathrm{O}^{\prime} \mathrm{Callaghan}$ et al., 1969; Waley, 1974) by measuring the decrease in absorbance at the substrate specific wavelength at $30^{\circ} \mathrm{C}$ in $3 \mathrm{ml} 0.01 \mathrm{M}-\mathrm{NaH}_{2} \mathrm{PO}_{4} / \mathrm{Na}_{2} \mathrm{HPO}_{4}$ buffer, $\mathrm{pH} 7 \cdot 5$. The specific wavelengths of the substrates are given in Table 5. One unit of $\beta$-lactamase activity was defined as the amount catalysing the hydrolysis of $1 \mu \mathrm{mol}$ substrate $\mathrm{min}^{-1}$, and activities are expressed as units (mg enzyme solution) $)^{-1}$.

Estimation of kinetic parameters. Using the purified enzyme preparation, the $K_{\mathrm{m}}$ and $V_{\max }$ values for several substrates were estimated from Lineweaver-Burk plots. The $K_{\mathrm{m}}$ values are expressed as $\mu \mathrm{M}$ and $V_{\max }$ values as $\mu$ mol substrate hydrolysed $\min ^{-1}$ (mg protein) ${ }^{-1}$.

Immunological methods. Rabbit antisera were produced against the purified enzyme preparation from strain GN7391. The first injection, $1 \mathrm{mg}$ protein in $1 \mathrm{ml} 0.15 \mathrm{M}$-saline, was administered subcutaneously. The second subcutaneous injection, $1 \mathrm{mg}$ protein in $0.5 \mathrm{ml}$ saline, was emulsified with $0.5 \mathrm{ml}$ complete Freund's adjuvant (Difco). After 3 weeks, a booster injection, $0.75 \mathrm{mg}$ protein, was administered in the marginal ear vein. Antisera were collected about 2 weeks after the last injection.

From these antisera, gamma globulins were precipitated by adding $\left(\mathrm{NH}_{4}\right)_{2} \mathrm{SO}_{4}$ to give $50 \%$ saturation. After stirring overnight at $5^{\circ} \mathrm{C}$, the precipitate was collected by centrifuging, then dissolved in and dialysed against $0.01 \mathrm{~m}$-phosphate buffer, $\mathrm{pH} 7 \cdot 0$. The solution was passed through a column of DEAE-cellulose pre-equilibrated with the same buffer.

The effect of the antibodies on $\beta$-lactamase was determined by a neutralization test of the hydrolysing activity of the enzyme. Enzyme solution (4 units) was incubated with various amounts of antibody in $0.2 \mathrm{ml}$ $0.01 \mathrm{M}$-phosphate buffer, $\mathrm{pH} 7.5$ at $37^{\circ} \mathrm{C}$ for $20 \mathrm{~min}$ and then left at $5^{\circ} \mathrm{C}$ for $18 \mathrm{~h}$. 
Table 1. Minimum inhibitory concentrations of various antibiotics and $\beta$-lactamase activities of Citrobacter freundii strains

\begin{tabular}{|c|c|c|c|c|c|}
\hline \multirow{2}{*}{$\begin{array}{l}\text { C. freundii } \\
\text { strain }\end{array}$} & \multicolumn{4}{|c|}{ Minimum inhibitory concn $\left(\mu \mathrm{g} \mathrm{ml}^{-1}\right)$} & \multirow{2}{*}{$\begin{array}{l}\text { Enzyme activity* } \\
\quad \text { (units } \mathrm{mg}^{-1} \text { ) }\end{array}$} \\
\hline & Cefmetazole & Cefoxitin & Cefazolin & Ampicillin & \\
\hline GN299 & 100 & 200 & 1600 & 800 & $1 \cdot 64$ \\
\hline GN324 & 50 & 200 & 3200 & 800 & $3 \cdot 63$ \\
\hline GN346 & 100 & 200 & 1600 & 800 & $4 \cdot 38$ \\
\hline GN492 & 400 & 800 & 3200 & 800 & 0.45 \\
\hline GN517 & 50 & 100 & 1600 & 800 & 0.60 \\
\hline GN726 & 50 & 100 & 800 & 400 & $0 \cdot 25$ \\
\hline GN930 & 100 & 200 & 1600 & 800 & 0.57 \\
\hline GN1021 & 100 & 400 & 1600 & 400 & $0 \cdot 18$ \\
\hline GN1376 & 100 & 200 & 800 & 400 & 0.01 \\
\hline GN7084 & 200 & 400 & $>3200$ & 800 & 4.06 \\
\hline GN7085 & 50 & 100 & 1600 & 400 & $0 \cdot 14$ \\
\hline GN7090 & 200 & 400 & 3200 & 1600 & 0.01 \\
\hline GN7091 & 100 & 200 & $>3200$ & 3200 & 0.58 \\
\hline GN7092 & 200 & 400 & $>3200$ & 3200 & 0.45 \\
\hline GN7093 & 200 & 400 & 3200 & 3200 & 3.89 \\
\hline GN7099 & 50 & 200 & 3200 & 800 & $3 \cdot 11$ \\
\hline GN7390 & $>400$ & $>400$ & 3200 & 3200 & 0.22 \\
\hline GN7391 & 400 & $>400$ & $>3200$ & $>3200$ & 9.01 \\
\hline GN7539 & 50 & 50 & 1600 & 3200 & $1 \cdot 14$ \\
\hline GN7544 & 25 & 200 & 100 & 3200 & $0 \cdot 35$ \\
\hline GN7545 & 50 & 100 & 200 & 3200 & 0.43 \\
\hline
\end{tabular}

Immunoelectrophoresis was done in $1 \cdot 2 \%(\mathrm{w} / \mathrm{v})$ agar containing veronal buffer, $\mathrm{pH} 8 \cdot 6$.

Amino acid analysis. The amino acid composition of the enzyme was determined as described by Spackman et al. (1958) and as previously reported (Fujii-Kuriyama et al., 1977), with an amino acid analyser (Hitachi model KLA-2).

\section{RESULTS}

Resistance levels and $\beta$-lactamase activities

All the strains of Citrobacter freundii examined had a high degree of resistance to cefazolin and ampicillin (Table 1). Six strains (GN324, GN346, GN7084, GN7093, GN7099 and GN7391) had high activities of $\beta$-lactamase (Table 1). The $\beta$-lactamases produced by these strains hydrolysed cephaloridine, cefazolin and cephalothin more rapidly than penicillins (Table 2). Cefmetazole and cefoxitin, both cephamycin derivatives, were not hydrolysed.

Citrobacter freundii GN7391 had the highest enzyme activity and it hydrolysed not only cephalosporins but also penicillins such as penicillin $\mathrm{G}$ and ampicillin. This strain, which has an R-plasmid-mediated penicillinase (Tajima et al., 1979) and a chromosomal cephalosporinase, was used as a source for purification of $\beta$-lactamase.

\section{Purification of $\beta$-lactamase}

Details of the purification procedure are given in Methods; a typical purification is summarized in Table 3. The penicillinase and cephalosporinase were separated in step 3 . The penicillinase was purified (see Methods) and identified as a type Ia penicillinase (Sawai et al., 1970a). The cephalosporinase was further purified as indicated in Table 3. After isoelectric focusing and subsequent fractionation, the $\mathrm{pH}$, enzyme activity and protein concentration in each fraction were measured. The peak of enzyme activity coincided with 


\section{Table 2. Substrate profile of $\beta$-lactamases from strains of Citrobacter freundii}

The rates of hydrolysis were determined at $30^{\circ} \mathrm{C}$ with substrate concentrations of $100 \mu \mathrm{M}$ (cephalosporins and cephamycins) or $200 \mu \mathrm{M}$ (penicillins). The rates given are relative to an arbitrary value of 100 for cephaloridine.

C. freundii strain

\begin{tabular}{|c|c|c|c|c|c|c|}
\hline Substrate & GN324 & GN346 & GN7084 & GN7093 & GN7099 & GN7391 \\
\hline Cephaloridine & 100 & 100 & 100 & 100 & 100 & 100 \\
\hline Cefazolin & 388 & 518 & 408 & 418 & 494 & 436 \\
\hline Cephalothin & 26 & 65 & 28 & 41 & 71 & 27 \\
\hline Cephalexin & 23 & 23 & 22 & 34 & 41 & 26 \\
\hline Cefmetazole & $<0.1$ & $<0.1$ & $<0 \cdot 1$ & $<0 \cdot 1$ & $<0 \cdot 1$ & $<0 \cdot 1$ \\
\hline Cefoxitin & $<0.1$ & $<0 \cdot 1$ & $<0 \cdot 1$ & $<0 \cdot 1$ & $<0 \cdot 1$ & $<0.1$ \\
\hline Penicillin G & $2 \cdot 5$ & $4 \cdot 7$ & $1 \cdot 7$ & $42 \cdot 9$ & $3 \cdot 3$ & $26 \cdot 5$ \\
\hline Ampicillin & $<0 \cdot 1$ & $<0.1$ & 0.2 & $30 \cdot 1$ & 0.5 & $13 \cdot 8$ \\
\hline Carbenicillin & $3 \cdot 0$ & $4 \cdot 9$ & 0.9 & $6 \cdot 2$ & 1.7 & $2 \cdot 7$ \\
\hline
\end{tabular}

Table 3. Summary of purification of $\beta$-lactamase from Citrobacter freundii strain GN7391

These results were obtained for purification from a 201 culture of strain GN7391. Activity was determined with $100 \mu \mathrm{M}$-cephaloridine as the substrate.

Procedure

1. Ultrasonic disintegration

2. Streptomycin treatment

3. Chromatography on Sephadex CM-50

4. Re-chromatography on Sephadex CM-50

5. Isoelectric focusing

6. Gel filtration on Sephadex G-200
Total protein

(mg)

8430

3500

$159 \cdot 1$

$121 \cdot 4$

$102 \cdot 6$

$78 \cdot 1$
Specific activity
(units $\mathrm{mg}^{-1}$ )

Recovery $(\%)$

100

$86 \cdot 4$

$69 \cdot 3$

$49 \cdot 7$

$40 \cdot 2$

$37 \cdot 3$

that of protein, at pI 8.6 (Fig. 1). Fractions around the peak (fractions 43 to 47 ) were pooled and applied to the Sephadex G-200 column. Elution of enzyme activity and protein coincided exactly and the specific activity in each fraction showed a constant value.

The purity of the lyophilized preparation was checked by polyacrylamide gel electrophoresis, SDS-polyacrylamide slab gel electrophoresis and immunoelectrophoresis. In polyacrylamide gel electrophoresis the enzyme activity and the stained band coincided, and SDS-polyacrylamide slab gel electrophoresis gave a single protein band. Agar gel immunoelectrophoresis using the anti-GN7391 antibody and the crude enzyme of $C$. freundii GN7391 gave a single precipitin arc, showing that the antibodies contained a single component reacting with crude enzyme; moreover, the precipitin arc for the antibody and the purified enzyme preparation was symmetrical with that of the crude enzyme.

These results indicated that the purified enzyme preparation was homogeneous.

\section{Physicochemical properties of the purified enzyme}

The molecular weight of the purified enzyme, determined by gel filtration through Sephadex G-200, was 38000 . From the electrophoretic mobility in the SDS-polyacrylamide gel, the subunit molecular weight of the enzyme was also estimated to be 38000 . Neutral sugar was not detectable in the purified enzyme by the phenol/sulphuric acid method (Dubois et al., 1956). These results show that the purified enzyme is composed of a single polypeptide of molecular weight 38000 .

The amino acid composition of the purified enzyme is given in Table 4. No cysteine was found. The pI was $8 \cdot 6$. 


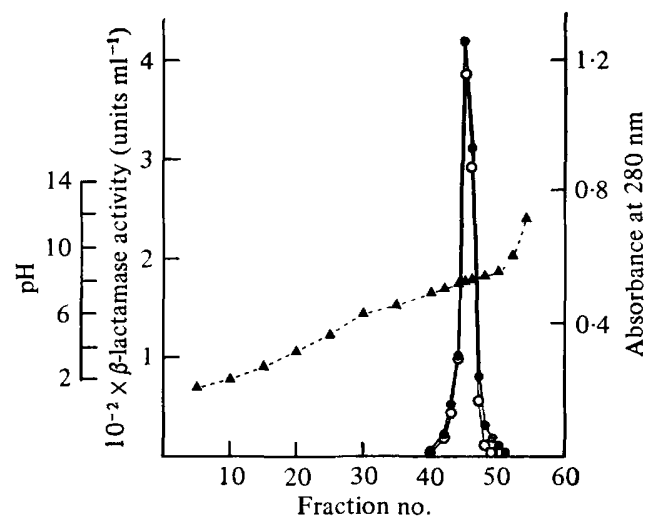

Fig. 1. Isoelectric focusing of $\beta$-lactamase from Citrobacter freundii strain GN7391. Step 4 fraction $(6 \mathrm{mg})$ was focused on a sucrose/ampholytes gradient $(\mathrm{pH} 3.5$ to 10$)$ at $5{ }^{\circ} \mathrm{C}$. Fractions $(2 \mathrm{~g})$ were collected and assayed for protein $(\bigcirc), \beta$-lactamase activity $(\bigcirc)$ and $\mathrm{pH}(\mathbf{\Delta})$.

Table 4. Amino acid composition of $\beta$-lactamase from Citrobacter freundii strain GN7391

$\begin{array}{lcc}\text { Amino acid } & \begin{array}{c}\text { Content } \\ \left(\mu \mathrm{mol} \mathrm{mg}^{-1}\right)\end{array} & \text { Residues* } \\ \text { Aspartic acid } & 0 \cdot 386 & 23 \\ \text { Threonine } & 0 \cdot 317 & 19 \\ \text { Serine } & 0 \cdot 309 & 18 \\ \text { Glutamic acid } & 0 \cdot 769 & 46 \\ \text { Proline } & 0 \cdot 412 & 25 \\ \text { Glycine } & 0 \cdot 506 & 30 \\ \text { Alanine } & 0 \cdot 633 & 38 \\ \text { Cysteine } & 0 & 0 \\ \text { Valine } & 0 \cdot 404 & 24 \\ \text { Methionine } & 0 \cdot 145 & 9 \\ \text { Isoleucine } & 0 \cdot 299 & 18 \\ \text { Leucine } & 0 \cdot 526 & 31 \\ \text { Tyrosine } & 0 \cdot 243 & 14 \\ \text { Phenylalanine } & 0 \cdot 114 & 7 \\ \text { Tryptophan } & 0 \cdot 165 & 10 \\ \text { Lysine } & 0.410 & 24 \\ \text { Histidine } & 0.084 & 5 \\ \text { Arginine } & 0 \cdot 227 & 14 \\ \text { Total } & 5.949 & 355 \\ \text { Ammonia } & 0 \cdot 773 & \end{array}$

* The calculated numbers of residues are based on an assumed molecular weight of 38000 .

\section{Enzymic properties of the purified enzyme}

The enzyme was most active at $\mathrm{pH} 8.0$ and its temperature optimum was $45^{\circ} \mathrm{C}$ under the conditions of assay. Iodine at $0.01 \mathrm{~mm}$ inhibited the enzyme activity but $0.5 \mathrm{~mm}$ $p$-chloromercuribenzoic acid did not.

The kinetic parameters of the enzyme activity toward cephalosporins, cephamycins and penicillins are given in Table 5 . The relative $V_{\max }$ with cefazolin, cephaloridine, cephalothin, cephalexin and cephradine was higher than with penicillins. Among the cephalosporin derivatives tested, cefamandole, cefuroxime and cefotaxime were resistant to hydrolysis by the $\beta$-lactamase. Cephamycins and semi-synthetic penicillins were hydrolysed to only a small extent by the enzyme and inhibited the enzyme activity competitively. 
Table 5. Kinetics of hydrolysis of $\beta$-lactam antibiotics by $\beta$-lactamase from Citrobacter freundii strain GN7391

\begin{tabular}{|c|c|c|c|c|}
\hline Antibiotic & $\begin{array}{l}\text { Assay wavelength } \\
(\mathrm{nm})\end{array}$ & $V_{\max } *$ & $\begin{array}{l}K_{\mathrm{m}} \\
(\mu \mathrm{M})\end{array}$ & $\begin{array}{r}K_{\mathrm{i}} \dagger \\
(\mu \mathrm{M})\end{array}$ \\
\hline Cephaloridine & 260 & 100 & 72 & \\
\hline Cefazolin & 263 & 288 & 254 & \\
\hline Cephalothin & 262 & 27 & 9 & \\
\hline Cephalexin & $262 \cdot 5$ & 24 & 10 & \\
\hline Cephradine & 263 & 20 & 15 & \\
\hline Cefsulodin & 263 & $0 \cdot 13$ & & 23 \\
\hline Cefamandole & 273 & $<0.01$ & & 0.019 \\
\hline Cefoperazone & 273 & 0.7 & & NT \\
\hline Cefotiam & 275 & 0.8 & & NT \\
\hline Cefuroxime & 262 & $<0.01$ & & 0.008 \\
\hline Cefotaxime & 264 & $<0.01$ & & 0.008 \\
\hline Ceftizoxime & 245 & 0.07 & & 0.036 \\
\hline Cefmetazole & 275 & 0.03 & & 0.044 \\
\hline Cefoxitin & 265 & 0.04 & & 0.23 \\
\hline Penicillin G & 232 & $2 \cdot 8$ & & NT \\
\hline Ampicillin & 235 & $0 \cdot 07$ & & $0 \cdot 11$ \\
\hline Carbenicillin & 235 & $<0.01$ & & 0.015 \\
\hline Cloxacillin & - & NT & & 0.005 \\
\hline Methicillin & - & NT & & $0 \cdot 015$ \\
\hline
\end{tabular}

Immunological properties of the purified enzyme

The effects of anti-GN7391 rabbit serum on the purified enzyme were studied as described by Jack \& Richmond (1970). The standard curve obtained when increasing quantities of the antibody were added to a fixed quantity of the purified enzyme (constant antigen titration) is shown in Fig. 2. The maximum degree of neutralization of the purified enzyme was approximately $75 \%$, even when an excess of the antibody was used. The reaction mixture was centrifuged to separate supernatants and immunoprecipitates. The supernatants had no $\beta$-lactamase activity with an excess of antibody. The remaining enzyme activity (some $25 \%$ of the initial activity) was not due to the presence of a different kind of $\beta$-lactamase unreactive with the antibody, but rather to precipitation of the antigenantibody complex possessing some enzyme activity.

The neutralizing capacity of the anti-GN7391 $\beta$-lactamase antibody was checked with various $\beta$-lactamases obtained from clinical isolates: five Citrobacter freundii, one Pseudomonas aeruginosa, one Pseudomonas cepacia, three Enterobacter cloacae, one Proteus morganii, one Proteus vulgaris, one Proteus rettgeri, one Serratia marcescens, one Bacteroides fragilis, three R-plasmid-carrying Escherichia coli and one R-plasmid-carrying Pseudomonas aeruginosa. The antibody neutralized enzymes from Citrobacter freundii strains (96 to 100\%) and from Enterobacter cloacae strains (92 to 95\%); none of the other cephalosporinases from Pseudomonas, Proteus, Serratia and Bacteroides were affected at all. There was no reaction with R-plasmid-mediated penicillinases.

\section{DISCUSSION}

In clinical practice, a large number of strains of Citrobacter freundii show resistance to penicillins and cephalosporins. A previous study (Sawai et al., 1970b) was devoted to precise characterization of various $\beta$-lactamases found in $C$. freundii. By combining several 


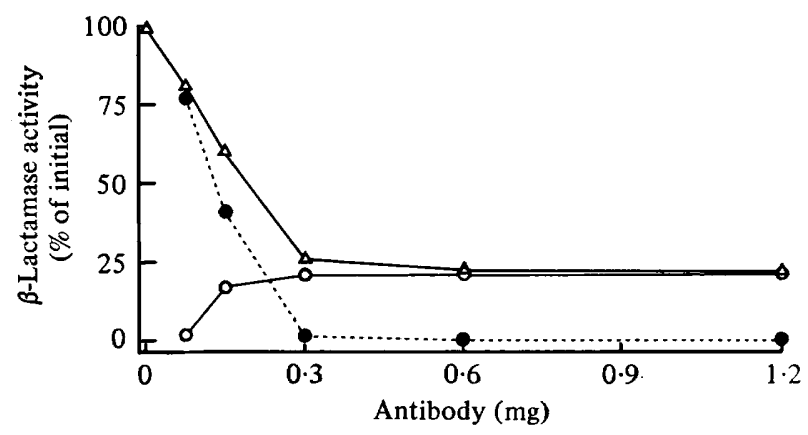

Fig. 2. Neutralization curve obtained for titration of $\beta$-lactamase from Citrobacter freundii strain GN7391 with anti-GN7391 $\beta$-lactamase antibody (constant antigen titration). Purified enzyme (4 units) was incubated with various amounts of antibody at $37^{\circ} \mathrm{C}$ for $20 \mathrm{~min}$ and then left at $5^{\circ} \mathrm{C}$ for $18 \mathrm{~h}$. Portions of the reaction mixture were assayed for $\beta$-lactamase activity $(\Delta)$. The remaining reaction mixture was centrifuged at $6000 \mathrm{~g}$ for $30 \mathrm{~min}$ to separate immunoprecipitates and supernatants. The precipitates were washed once with saline, and then the $\beta$-Jactamase activities of the supernatant fractions $(O)$ and suspended precipitates $(O)$ were assayed.

methods, including isoelectric focusing and neutralization with antisera, the authors were able to characterize differences in isoelectric point, molecular weight and immunological properties of $\beta$-lactamases in C. freundii.

The $\beta$-lactamase from $C$. freundii GN7391 presents a cephalosporinase profile as for class I $\beta$-lactamases described by Richmond \& Sykes (1973) and as for typical cephalosporinases described by Sawai et al. (1968). As indicated by $K_{\mathrm{m}}$ and $V_{\max }$ values, this enzyme has a strong affinity and a high activity on cephalosporin derivatives and a low activity for ampicillin, novel cephalosporins and cephamycins. The GN7391 $\beta$-lactamase shares other properties of the class I $\beta$-lactamases: inhibition by cloxacillin and resistance to $p$-chloromercuribenzoic acid.

Isoelectric focusing gave a $\mathrm{pI}$ of 8.6 for the $\beta$-lactamase. This is consistent with a previous report (Matthew \& Harris, 1976) of $\mathrm{pI}$ values of $8 \cdot 3$ and $7 \cdot 5$, respectively, for $\beta$-lactamase from $C$. freundii strains $1461 \mathrm{E}$ and $1088 \mathrm{E}$, suggesting that cephalosporinases are basic proteins.

The $\beta$-lactamase protein of strain GN7391 has been detected among other strains of C. freundii, such as GN324, GN346, GN7084, GN7093 and GN7099, isolated from clinical materials, by the immunoelectrophoretic analysis and neutralization test. The protein also cross-reacted with chromosomal $\beta$-lactamases from strains of Enterobacter cloacae, although these $\beta$-lactamases have different molecular weight (approx. 42000; Minami et al., $1979)$ and $\mathrm{pI}$ values $(9 \cdot 2$ to $9 \cdot 3)$. Cross-reaction between chromosomally mediated $\beta$-lactamases from different genera has been reported for Enterobacter cloacae and Proteus morganii (Letarte et al., 1977) and Alkalescens dispar, Escherichia coli and Shigella sonnei (Sykes \& Matthew, 1976).

\section{REFERENCES}

ANDREws, P. (1964). Estimation of the molecular weight of proteins by Sephadex gel filtration. Biochemical Journal 91, 222-233.

Bill, N. J. \& WAshington, J. A., II (1977). Comparison of in vitro activity of cephalexin, cephradine, and cefaclor. Antimicrobial Agents and Chemotherapy 11, 470-474.

CoWAN, S. T. \& STEEL, K. J. (1974). Manual for the Identification of Medical Bacteria, 2nd edn. Cambridge: Cambridge University Press.

DAvis, B. J. (1964). Disc electrophoresis II. Method and application to human serum proteins. Annals of the New York Academy of Sciences 121, 404-427.

Dubois, M., Gilles, K. A., Hamlton, J. K., Rebers, P. A. \& Smith, F. (1956). Colorimetric method for determination of sugars and related substances. Analytical Chemistry 28, 350-356.

Fuji-Kuriyama, Y., Yamamoto, M. \& Sugawara, S. (1977). Purification and properties of betalactamase from Proteus morganii. Journal of Bacteriology 131, 726-734. 
JACK, G. W. \& Richmond, M. H. (1970). A comparative study of eight distinct $\beta$-lactamases synthesized by Gram-negative bacteria. Journal of General Microbiology 61, 43-61.

Letarte, R., Felix, M. D., Pechere, J. C. \& LEPROHON, D. A. (1977). Enzymatic and immunological characterization of a new cephalosporinase from Enterobacter aerogenes. Antimicrobial Agents and Chemotherapy 12, 201-205.

Matthew, M. \& Harris, A. M. (1976). Identification of $\beta$-lactamases by analytical isoelectric focusing: correlation with bacterial taxonomy. Journal of General Microbiology 94, 55-67.

Minami, S., Inoue, M. \& Mitsuhashi, S. (1979). Purification and properties of $\beta$-lactamase from Enterobacter cloacae. In Proceedings of the 8th Gunma Symposium on Microbial Drug Resistance, pp. 52-53. Edited by S. Mitsuhashi. Gunma: Gunma University Press.

Newsom, S. W. B., Marshall, M. J. \& Harris, A. M. (1974). Enterobacteria, $\beta$-lactam antibiotics and $\beta$-lactamases in clinical practice. Journal of Medical Microbiology 7, 473-482.

O'Callaghan, C. H., Muggleton, P. W. \& Ross, G. W. (1969). Effects of $\beta$-lactamase from Gram-negative organisms on cephalosporins and penicillins. In Antimicrobial Agents and Chemotherapy-1968, pp. 55-63. Edited by G. L. Hobby. Maryland: American Society for Microbiology.

Richmond, M. H. \& Sykes, R. B. (1973). The $\beta$-lactamases of Gram-negative bacteria and their possible physiological role. Advances in Microbial Physiology 9, 31-88.

Sawai, T., Mitsuhashi, S. \& Yamagishi, S. (1968). Drug resistance of enteric bacteria. XIV. Comparison of $\beta$-lactamases in Gram-negative rod bacteria resistant to $\alpha$-aminobenzylpenicillin. Japanese Journal of Microbiology 12, 423-434.

Sawai, T., TAKahashi, K., Yamagishi, S. \& MrtsuHaSHI, S. $(1970 a)$. Variant of penicillinase mediated by an $\mathbf{R}$ factor in Escherichia coli. Journal of Bacteriology 104, 620-629.

Sawai, T., Mitsuhashi, S. \& Yamagishi, S. (1970b). Stability of various derivatives of 7-aminocephalosporanic acid and 6-aminopenicillanic acid to cephalosporinases from Gram-negative bacteria. In Progress in Antimicrobial and Anticancer Chemotherapy, vol. 1, pp. 410-415. Edited by $\mathrm{H}$. Umezawa. Tokyo: University of Tokyo Press.

Spackman, D. H., Stein, W. H. \& Moore, S. (1958). Automatic recording apparatus for use in the chromatography of amino acid. Analytical Chemistry 30, 1190-1206.

Sykes, R. B. \& MatThew, M. (1976). The $\beta$ lactamases of Gram-negative bacteria and their role in resistance to $\beta$-lactam antibiotics. Journal of Antimicrobial Chemotherapy 2, 115-157.

TAJIMA, M., TAKenouChI, Y. \& Sugawara, S. (1979). Purification and properties of $\beta$-lactamases from Citrobacter freundii. In Proceedings of the 8th Gunma Symposium on Microbial Drug Resistance, pp. 56-57. Edited by S. Mitsuhashi. Gunma: Gunma University Press.

VERBIST, L. (1976). Comparison of the antibacterial activity of nine cephalosporins against Enterobacteriaceae and nonfermentative Gram-negative bacilli. Antimicrobial Agents and Chemotherapy 10, 657-663.

WALEY, S. G. (1974). A spectrophotometric assay of $\beta$-lactamase action on penicillins. Biochemical Journal 139, 789-790.

WEBER, K. \& OSBORN, M. (1969). The reliability of molecular weight determinations by dodecyl sulfate-polyacrylamide gel electrophoresis. Journal of Biological Chemistry 244, 4406-4412.

Yamanaka, Y., Tajima, M. \& Nakazawa, S. (1973). Purification and characterization of $\beta$-lactamase from clinically isolated $E$. coli strain No. 24 . Chemotherapy, Tokyo 21, 1179-1183. 